Chapter 8

\title{
Customer Orientation of Current and Future Entrepreneurs in Research Using Projection Methods - Implications for Education
}

\author{
Anna Pawłowska \\ Additional information is available at the end of the chapter \\ http://dx.doi.org/10.5772/59071
}

\section{Introduction}

Changes in the economy and labour market mean that the process of teaching entrepreneurship is becoming increasingly important and is subject to impacts on a wide scale. For example, entrepreneurship is becoming an instrument for the European Union [1], supporting, inter alia, the solution to the problem of youth unemployment. The correctness of this trend is confirmed, for example, by Matlay's study [2], which followed the fate of 64 graduates from a school of entrepreneurship. It turned out that "over the ten-year period under scrutiny, none of the graduates became unemployed or acquired employee status."

The Polish operational program for 2014-2020 schedules a Program of Knowledge, Education and Development with 4.69 billion Euros allocated to it [3]. The effectiveness of programs and methods of teaching entrepreneurship are therefore becoming crucial for their optimum utilization.

This study analysed the results of a diagnosis carried out using the methods of projection, on the shaping of consumer orientation competence that is being developed in the recipients of these educational activities. Areas were also identified areas where attention should be focused and which should be impacted on, and ways are identified in which this can be done in the course of teaching. It is a response to the objection to the schools of entrepreneurship from some researchers that the programs and teaching methods do not fully meet the needs of people who are to lead companies in the future. 


\section{Education and the development of entrepreneurship}

Entrepreneurship researchers have indicated that the process of teaching entrepreneurship does not proceed satisfactorily enough to help enterprising individuals cope effectively in business. Rae [4] suggests that "... the skills traditionally taught in business schools are essential but not sufficient to make a successful entrepreneur". Similarly, Kirby [5] asserts that: ...often such programmes equate entrepreneurship with new venture creation or/and small business management and educate "about" entrepreneurship and enterprise rather than educating "for" entrepreneurship [...]".

Some facts from the development of Polish entrepreneurship can confirm this. According to the Polish Agency for Enterprise Development report [6] on the state of the small and mediumsized enterprise sector in Poland in 2011-2012, Poles are generally an enterprising nation. The level of entrepreneurship measured as a proportion of entrepreneurs or those among the employed who are planning to start a business is above the EU average. According to Eurostat data, in Poland there are 1.52 million enterprises, which puts the Polish economy in sixth place in the EU in terms of numbers. This clearly reveals a high propensity to establish businesses. Poland is one of the EU countries with the highest number of newly established enterprises in 2010, ranking second after France. Poland definitely excels in this respect, because "the intention to start your own business" is declared by $22 \%$ of adults, in comparison with the EU where there are $13 \%$. At the same time the number of new companies formed over the entire period 2003-2012 was higher than those liquidated.

Nevertheless, although both categories showed an upward trend, the number of liquidated companies increased slightly faster compared to those emerging. According to CSO data [6] three out of four companies in Poland survive the first year of operation (in 2011, the survival rate was $76.6 \%$ ). In subsequent years, the survival rate clearly falls - to $54 \%$ in the second, and $32 \%$ in the fifth year of operation. In any case, this is not just a characteristic of Polish entrepreneurship. Sveinn Vidar Gudmundsson and Christian Lechner reported that according to Nobel [7] in general, from 30 to $40 \%$ of entrepreneurial firms are complete failures and many are bought out or never bring the expected return on investment, meaning that the real failure rate can be 70 to $80 \%$.

The possible causes of such a situation are interesting. Some indication may be that Poland achieves lower than the EU average results for the index "percentage of adults who agree that school education helped them develop a sense of entrepreneurship" (Poland - 45\%, EU - 50\%) [6]. Perhaps the motivation to start your own business does not go hand in hand with the skills to run it, for which education is at least in part responsible.

In Poland, entrepreneurship in formal education begins in secondary school, starting with ages 14-16 years and continues in high school. According to the Eurydice Report [8], Poland is one of the eight countries that have introduced Entrepreneurship as a compulsory subject. Moreover, in high schools, there is a new complementary additional subject "Economics in practice." At this stage of education, in the reports prepared for the European Commission, Poland is highly evaluated in terms of implementation of the recommendations in the field of 
Entrepreneurial Education. At an academic level, the situation is already much less optimistic and difficult to assess reliably due to the lack of detailed research in this area. Because education at university level in Poland, as in other European countries is still decentralized, implemented training standards for Economics and Management negligibly reflect the recommendations of the European Commission.[9] Particularly disadvantageous is the fact, that the content of entrepreneurial education has been introduced into the standards of education uneconomically especially in non-business studies according to the report of the European Commission Enterprise and Industry Directorate-General: Entrepreneurship education in non-business schools is almost non-existent, and tends to be viewed as low priority and as a "soft" subject compared with the hard sciences. A recent initiative is the nationwide programme "Dynamic entrepreneurship", geared primarily to students in the nonbusiness field. In Poland, the Ministry of Science and Higher Education has provided financial support to the Dynamic Entrepreneurship Programme to train entrepreneurship lecturers from 20 nonbusiness institutions. " [10]

The effects of entrepreneurial education are still rated negatively by business representatives: "I disagree with anyone's view who says that everything is well with the entrepreneurship education in Poland. Truthfully the subject exists, but it is too academic, and most of those who have experienced this, complain of it being over-theoretical and boring. "[11]

\section{Restrictions on the effectiveness of entrepreneurship education}

However, the problem arises of where to look for the sources of limitations on the effectiveness of entrepreneurial education. The situation is complicated to the extent that directly questioning participants, graduates, or entrepreneurs about their educational needs provides no guarantee of obtaining information that would help solve the problem. The more so that a "number of factors can influence their perceptions of, and need for entrepreneurship education and/or vocational training" [12]. For this reason, when improving entrepreneurship programs, we cannot rely solely on the needs expressed by the participants, as it is highly likely they are not able to fully reliably formulate these needs. So let's take a closer look, examining the scientific achievements, then identify and examine potential sources of restrictions on the effectiveness of entrepreneurship education.

The first hypothesis to emerge - that the cause lies in the personality traits of the learners - is unsatisfactory. This is indicated, for example, by Hansemark's study [13]. He diagnosed the achievement motivation and locus of control in participants in projects supporting the development of entrepreneurship, and eleven years later checked to see whether they were doing business for themselves. It turned out that there was no relationship between achievement motivation and propensity to start their own business. In the case of locus of control (LOC) there was a correlation, but it only occurred in the case of men, suggesting that for women other variables are likely to be more important. Hansemark [13] formulates an interesting explanation of the reasons for this result. He draws attention to the fact that the features identified in the model of an effective entrepreneur have been established in studies 
of entrepreneurs, i.e. people who already run their own business. The author hypothesizes that perhaps many of the characteristics are formed in the course of business, among which may be achievement motivation and locus of control. This does not mean at all that before starting any economic activity the individual must be at a comparable level. It can therefore be assumed that personality is an important factor in determining efficiency in business, as shown by many studies, but is not sufficient. Therefore it is a foundation, to which should be added everything that the educational process can offer. The question this arises is - what is missing in the learning process, and which may be important for efficacy?

J.C. Sánchez drew attention to an interesting source showing the effectiveness of entrepreneurial education. He carried out an experimental study showing that training participants developed entrepreneurial skills, such as self-efficiency, pro-activeness, risk taking, and the intention of self-employment. Participation has showed achievement with higher scores as opposed to those who did not participate in it, which was a distinct merit of the educational process. At the same time, however, J.C. Sánchez sought to answer the question what was so special about this course that achieved the learning outcomes. The fact is there are studies that show the ineffectiveness of educational activities in the field of entrepreneurship. "In this sense we must point out other aspects deriving from our program that are in line with what Rae has called the main role of entrepreneurship education: sparing ideas of what it means to be an entrepreneur and creating critical awareness. This aspect was also pointed out by Bakotic and Kruzic, who argue that entrepreneurship education programs help to augment perception of the important aspects of entrepreneurship as well as provide a realistic view of the problems it can involve." [14] Therefore it is worth looking deeper at the process of the entrepreneurial education.

\section{The role of cognitive structures}

Most probably the problem is very complex. This study focuses on certain guidelines provided by cognitive psychology. The starting point is the fact that education is focused on providing knowledge and information which are important from the point of view of running a company. It is therefore interesting to look at how the individual copes with information about the world, and here in particular the reality of running your own business, what they do with it, and how relevant it is to their behaviour.

According to cognitive psychologists the individual accumulates knowledge about themselves, others, and the world around them, in cognitive structures. It is on this knowledge that how s/he perceives and interprets themselves, the world, other people, and his/her own relationship with the world, depends. This then affects his/her behaviour. Also of interest to this study are the decisions s/he takes, for example, in the course of running their own business. How the entrepreneurial activity runs will depend on his/her perception and interpretation of the business world, its rules and the principles governing it and himself/herself in relationship with them, which is reflected in his/her beliefs and perceptions. 
The information gathered by an individual is generalised in the form of schemata. A cognitive schema is knowledge abstracted from experience, useful for interpreting phenomena, a kind of container of new and similar elements of experience [15]. Schemata are created in social interactions and are subject to social arrangements. Among these are scripts, also including roles, and activities, which are cognitive representations of reality. These allow the individual to orient themselves in the world and predict the effectiveness of activities and likelihood of events, such as the set of behaviours typical of an entrepreneur. They also cover different spheres of life, in fact including everything that is associated with business activity. Thanks to them, the world is structured, and individuals know what to do, how to react, etc. As a result, the content of these cognitive schemata and scripts determine the type and form of individual activity. Some of these include running a company. It can therefore be assumed that the course of the entrepreneurial process also depends on them. The question is what relationship arises between cognitive schemata and the formal knowledge that has been transferred in the course of teaching.

This is explained by Seymour Epstein's Cognitive-Experiential Self Theory (CEST) [16]. According to this, the individual processes information in two systems: experiential and rational. In the experiential system information is collected from direct experience and on this basis response patterns are formed, resulting in specific behaviours. It is important that it is an automatic learning system that extends beyond the control of consciousness, and the individual at best knows its effects, but is often not fully aware of it. "It works in a preconscious, automatic, non-verbal, associative, fast, effortless, concrete, and at the same time comprehensive manner, and is strongly associated with emotions" [16]. It conditions adaptation processes. In the experiential system, there are schemata that are generalizations of one's own, emotionally important experiences. They are preconscious, implicit theories of self and the world and are descriptive and motivational (if-then, means-end relations).

The rational system works with problem-solving processes involving thinking and reasoning. It includes beliefs, i.e. conscious, explicit theories of self and the world. Their sources are the individual's own experiences and social (cultural) communication. Acquisition of beliefs occurs through logical reasoning and rational elaboration of experiences. This process "is conscious, oriented, mostly verbal, not too fast, requires effort, abstract, analytical and mostly free from the direct influence of emotion". [16]

We can assume that the content of the individual's cognitive structures concerning running their own business are in the form of cognitive schemata, perceptions and beliefs, as a private theory about what to do to function in business, regardless of what is communicated in the course of formal education. Cognitive psychologists assume that the two systems operate in parallel and that they interact.

The importance of these schemata and beliefs is indicated by the results of Koellinger, Minniti and Schade [17]. They researched entrepreneurs from 29 countries including Poland using the Global Entrepreneurship Monitor (GEM) database. According to them, subjective beliefs, and perception of self and the environment are essential for entrepreneurial activity. These in turn are influenced by many factors such as the culture, history, and economic realities of a given country. In their opinion, entrepreneurial decisions are largely based on perception and 
cognitive mechanisms. This may for example lead to over-confidence and result in the entrepreneur overestimating their control over events, and assessing risk incorrectly.

From the point of view of the development of entrepreneurship it is interesting and important to see how the contents of the cognitive structures in people who want to run their own business, in the form of schemata, scripts, actions, beliefs and perceptions, interact with those that are transferred during formal learning. It is precisely the automated and not fully conscious cognitive schemata that may be crucially important. This is due to the specific nature of entrepreneurial activity. During this, it is necessary to activate the processes of decisionmaking and behaviours which are non-routine and non-schematic. It is not possible to use the set of algorithms which have a foreseeable result specific to each of the situations in which an entrepreneur may find themselves.

The education process may deliver the instruments, tools, and guidelines, but these may not be enough. They are not universal. The variability and unpredictability of the various business situations requires the application of skills outside the schemata. It is then that the automatic reactions arising from an individual's beliefs and perceptions on how to act in a given situation are activated. The direction is then provided by assumptions as to how things in the world of business are in this case and ensuring effective operation within it. Perhaps the individual activates a script for action which automatically plays shaped by observation of the world and the behaviour of others. It may be that this non-routine response is inconsistent with what education has tried to convey and inapplicable to the rules of the market. However, the individual may not be aware of this and act in the conviction of the rightness of their actions. Thus the acquired school knowledge - a set of procedures to be used in the right way and appropriate to the circumstances - is not applied correctly. The entrepreneur must decide what s/he should use from this kit, and that depends on his/her beliefs, ideas, etc. S/he is in a different situation form, for example, an official who must stick to narrowly defined rules. So if an entrepreneur is guided by erroneous premises, even the best method, for example a marketing tool, used inappropriately, will not bring the expected results.

The more so that according to Zaleśkiewicz [18] entrepreneurs prefer informal information (advice from others) from formal (publications, etc.), because they prefer an intuitive way of thinking that is associational, rather than a systematic and analytical procedure. Manimal [18], however, argues that entrepreneurs use a variety of simplifications in thinking and have an internal orientation in decision making - a tendency to follow their own ideas, avoiding such expert opinion. This could suggest that they are oriented towards and have more confidence in what works in their cognitive structures as a result of their own experiences and thoughts. The objectivised knowledge administered during formal education and based on rational facts is less important to them.

This is also confirmed by Simon [19], "Entrepreneurship seems strongly linked to biased perceptions rather than measures of objective reality, so researchers are turning to entrepreneur's cognitive biases to explain not only entrepreneurial firm creation but also failure." The validity of this line of research is also confirmed by studies on the mindset of entrepreneurs by J. Michael Haynie, Dean Shepherd, Elaine Mosakowski and P. Christopher Earley [20]. 
The importance of this is apparent at the moment the decision to start your own business is taken, which is nothing other than taking a specific career path. The concepts of vocational development by Super and Gottfredson [21] look precisely at the importance of cognitive processes in the process.

According to Gottfredson [21], in choosing a profession the individual uses information on themselves and the professional environment. Based on this, s/he creates an image of him/ herself in the occupational context, and thus a set of ideas arise concerning the occupations a cognitive map of occupations which may be of interest. The type of information contained in this cognitive map of occupations is determined by the individual's course of action.

Another proponent of developmental theories, Super [21], draws attention to the importance of the individual's self-image, emphasizing that this is a subjective idea of him/herself in a particular role, situation, or social position, and is a source of assessment of his/her own capabilities in the roles undertaken. He also introduces the idea of the vocational self-concept, which is shaped by observing the work situation, identification with others, and with the overall environment.

It should be noted that the information on which the individual makes career decisions is subjective in nature and is the result of their relationship with the environment. So the individual is as if sentenced to the fact that the information obtained is not always objective, but is a variety of stereotypes, generalizations and simplifications functioning in a given society and transferred to them during socialization. This applies both to self-perception as well as ideas about occupations.

According to these concepts of choice of occupation, in this case, the decision to be an entrepreneur is taken on the basis of the contents of the cognitive mental map, and relates to one's own "I", the occupation, and the occupational environment. Since these are ideas about social reality, it is possible to identify in them the same elements that cognitive psychology includes in the cognitive representation of the social world. "Social reality is represented in our minds in the form of events and social activities that have their actors, along with objectives, conditions for activation, barriers, and typical ways of overcoming them." [22] Reykowski writes, however, that cognitive structures include "representations of specific objects: individuals, institutions, symbols, places, objects that surround an individual with whom s/he remains in stable relationships. The network of these relationships determines the nature of the individual-world relationship"[23]. In this case, this means the world of entrepreneurship. At the same time a cognitive schema, in addition to descriptive information, also contains data about the emotional relationship to the objects contained therein.

The cognitive map of occupations also includes information about the social roles realised while pursuing a given occupation, in this case by entrepreneurs. In the social reality, individuals play roles, creating a kind of storyboard drama which is played out in the entrepreneurial environment. [24] The entities in these relationships behave according to the descriptions of their role and others associated with the occupation.

It can thus be concluded that an individual acts as an entrepreneur in accordance with how s/ he imagines him/herself, defines his/her role, and how s/he identifies with other individuals, 
their attributes and motives, and rules of operation. This perception of the world will determine his/her decisions, and its relevance to reality will determine their effectiveness in running a business.

From the perspective of these theories, it therefore seems particularly important to examine the cognitive map of the mind to reach these functional aspects of the entrepreneurial individual. There must be a correspondence between formal knowledge and the beliefs about the company, the rules by which it acts and the goals to pursue. The suspicion that there might be inconsistency in this is justified, for example when we take into account the history of the development of Polish entrepreneurship. In the earlier, communist, economic system, any entrepreneurial initiative was gradually destroyed. Many myths and beliefs were also created on the subject that have been saved in the individual's cognitive system and act like Hofstede's cultural programming [25], and may constitute an important barrier to the development of business activity in Poles [26].

\section{Customer orientation}

From the perspective of the theory of professional development, it can be assumed that the ideas and beliefs about the world of business contained in cognitive structures and the cognitive map of occupations affect the motivation for starting your own business. This motivation can therefore be seen as a manifestation of a belief by which individuals are guided.

As we know from Wickham's research [27], one of the motives for founding a firm is when the entrepreneur stands slim chances of finding a job, and being self-employed is the most advantageous solution for him/her. The second type of motivation stems from the fact that the entrepreneur notices a market opportunity and decides to run his/her own company. Among other things which distinguish the two types of motivation is the object towards which the action is directed. In the first case, the focus is on the person starting the company. As a further consequence, it can be predicted with high probability that the entrepreneur will act to meet their own needs, and not those of the customer, as might be expected from the second type of motivation to start their own business. This limits the potential profits of the company and will only allows him/her to maintain it in very favourable market conditions. There is the risk that such people do not fully identify and understand the rules of the market game.

This relationship with the customer can be very important for the development of the newlyestablished company.

K. Tajeddini, U. Elg and M. Trueman refer to a series of studies from various sources indicating the importance of customer orientation. "There is clearly a need for a customer-focused strategy if companies are to survive in the long term. Furthermore, as recognition of the economic significance of small firms has grown research has found that customer orientation is especially important." [28] They also found that "those entrepreneurial orientated smallsized retailers who tend to be proactive in anticipating the latent needs of customers are able to respond that current and future customer needs and wants, thereby generating a pioneering advantage over competitors" [28]. 
The demonstration of such a relationship allows us to draw the conclusion that customer orientation is not something natural, even when you have experience of running your own business and regular contact with customers. It can thus be assumed that the mere transfer of rational knowledge, such as marketing, is not sufficient to shape this orientation. This is confirmed by G. Morgan's statement (...) that "it is impossible to develop new ways to organize and manage, while still thinking the old way". [29]

This means that cognitive schemata, perceptions, and beliefs about clients include content that, intuitively and automatically applied, can lead to non-proeffective behaviours and decisions.

The aim of this study is to reach precisely this content, to determine the level of consumer orientation competency (COC).

Establishing a competence-based approach involves the allegation formulated against entrepreneurship education that, as Kirby says, "only rarely... is the focus on developing in their students the skills, attributes and behaviour of the successful entrepreneur". [30] According to the general definition, competence consists of the knowledge, skills and attitudes, and its determinants are specified behaviours. Kirby's accusation thus relates to the competency aspects of the individual's functioning in business. This analysis can identify potential areas of special influence in shaping entrepreneurial competence.

In this study, the competence of customer orientation will be construed in accordance with Brown's approach as a behavioural construct, to observe "a tendency or predisposition to meet customer needs". [29]

This should be distinguished from the understanding that "in marketing philosophy, customer orientation seeks to measure the extent to which decisions and activities in the organization are customer-based. Alternatively customer orientation in service firms is directly related to perceptions of quality, employee performance and service environment, leading to successful external marketing, enhanced customer satisfaction, and enhanced company performance" [29]. For example, this type of study was conducted Olalekan Asikhia among Nigerian small and medium-sized enterprises [31].

The approach presented in this paper focuses on the individual and their cognitive schemata, perceptions and beliefs about the customer. It is assumed that the individual has a high customer orientation competence if this content reveals a high awareness of the importance of the customer, orientation on active recognition of their needs, and addressing these in the course of cooperation. In addition, it is recognised that those so minded would indicate that they need knowledge about the customer to conduct business effectively. It is a quest for answers to the questions:

- Do they believe in the importance of the customer for their business?

- Do they focus on identifying and satisfying their needs?

- What action would they potentially to take towards the customer?

- Do they need knowledge about the customer? 


\section{Research method}

An important moment for the realization of this research goal was the choice of diagnostic method. However, the objective of the research in this paper was to reach the content of cognitive schemata, which are largely unconscious and instinctive. Asking the questions directly would make the respondents say what they think is right, and not what is due to their actual beliefs. This would be no different from what is obtained from conventional tests of knowledge. The resulting research material would not be credible, and it would be difficult to predict their behaviour in the realities of business based on it. Therefore, the most appropriate approach in this situation seemed to be to use a qualitative approach and psychological projection techniques.

According to Sęk, projection methods show the "subjective and subject-specific way of perceiving and constructing the environment" [32], i.e. what is needed in the problem being analysed. Kowalik, on the other hand, notes that projection techniques can lead in varying degrees to the appearance of projection. In contact with the projection stimulus this "may lead to the projection of unconscious or masked content, or a simple expression of conscious and accepted psychological content". [33] The use of projection methods for the diagnosis of beliefs and ideas about the role of the customer in running a company assumes a simple mapping of cognitive representation of the world in response to the projection stimulus. This has the advantage that, "to a greater extent than clearly structured material, the projection material [...] gives a better insight into the phenomenological world of the individual's experience, allows us to recognize their personal patterns of structuring and communicating experience, and reveals the dominant default social context of their activities". [34] Since this is a diagnosis of an imaginary business reality and the customer's place within it, we are dealing with a different application of this method than in clinical psychology, which seeks to capture the individual's defence mechanisms.

Using this approach, two diagnostic tools were constructed. One of these was an unfinished sentences test modelled on the Rotter Incomplete Sentences Blank RISB. This is a semistructured projection technique, which requires the test subject to finish a sentence, adding a completion to the initial given words (called stems). It is assumed that the sentences created by the respondent reflect their attitudes, motives, aspirations, desires, and conception of the surrounding reality. In finishing the sentence, the respondent "projects" their own attitudes and views on various aspects of life, thus making it possible to reach the sources and motives of their conduct. The test used in this study was specifically designed for this purpose. It is consistent with the methodological assumptions that "the unfinished sentences test, like other projection techniques, is constructed separately for each research problem". [35] This is important for consideration of the purpose of the study and the type of data that we wish to obtain.

For the second diagnostic tool, a test was used where the "projectionality" stems from the use of metaphor. According to G. Morgan, metaphor is "the basic overall form of experience through which individuals engage, organize and understand their world" [36]. It stems from the assumption that "we see things not as they are in objective reality, but rather as they appear 
in our experience" [37]. "[Thus] metaphor is an expression of our experience" [37] and "in most cases it is not about the truth or falsehood of the metaphor, but about the perception and conclusions that flow from it, and the actions sanctioned by it. In all aspects of life (...) we define a new reality in metaphorical terms, and then act guided by these metaphors. We draw conclusions, set goals, make commitments, and realize plans on the basis of how we partially organize our experience, consciously or unconsciously, but through metaphor." [37]

Therefore, based on knowledge of the metaphor with which the individual describes their company, it is possible to predict actions, procedures, type of decisions taken, and recognized rules, principles, etc. Leaving the respondents the freedom to associate and choose metaphors, the projective nature of the test is maintained and limits interference from the researcher and the simplifications that might ensue. Metaphor shows the cognitive functioning of a study subject, taking into account the emotional aspect of the issues. The metaphors are closer to the "average" individual, more common and inspiring, and therefore easily reach their imagination. The respondent, in describing the situation metaphorically, feels relatively safe, presenting their own perspective indirectly. With a direct question, the respondent could hide important details, especially emotional ones. This method of using projection methods for the diagnosis of consumer orientation competency has high incremental accuracy, indicating the extent to which the tool provides new information that is difficult or impossible to obtain using other techniques. [38] Examples of studies of this nature include the author's other research work [39] [40]. L.D. Sargent, Ch. D. Bataille, H.C. Vough, M. D. Lee used metaphor analysis to examine the meanings of retirement for a group of retired Canadian executives and managers. [41]

The tools constructed for the needs of the present study consist of the following projection impulses. The Unfinished Sentences Test contains the following stems:

- The most serious risk in running your own business...

- Factors hampering running of the company...

- In running a business what would help me...

The Metaphor Questionnaire was constructed in two versions, each addressed to a different group of respondents, as described in the next section.

Metaphor Questionnaire Version I contained the following instructions:

- Compare your company to any vehicle.

- What does the customer do in this vehicle?

- Who else is with you in this vehicle?

Metaphor Questionnaire Version II contained the following instructions:

- Compare your company to any vehicle.

- What does the customer do in this vehicle? 


\section{Research course}

The study was conducted independently in two stages. The first survey was conducted in November 2008 among participants in the European Social Fund project conducted at the Faculty of Management at Warsaw University "Entrepreneurship. Let's start our own company". It was attended by 22 people ( 10 women and 12 men) who, due to the fact that the condition for joining the project was to prepare a business plan, will hereafter be called the "entrepreneurs". As participants in the project, they received funding to start their own business, training, and supervision from management professionals. They exclusively completed Metaphor Questionnaire Version I.

The second study was conducted in April 2011. This was attended by students of I and II year fixed full-time and evening courses of the Faculty of Management at the University of Warsaw. Within this range, a group of people was isolated declaring that in the future they intend to start their own company (76 people, including 50 women and 26 men) and a second, not planning self-employment (21 individuals, including 14 women and 7 men). They completed the Incomplete Sentences Questionnaire and Metaphor Questionnaire Version II. Analysis of the results focused on the group planning to start a business. The second group represents a point of reference, but as it was far fewer in number, it cannot be the basis for a full comparative analysis, although some issues were identified for further investigation.

\section{Analysis of research results}

In order to analyse the data obtained, separate categories were assigned related to consumer orientation competence. For a more complete picture of the situation, other categories were also taken into account if this was justified by a reasonable response frequency from the subjects.

The table below shows the categories into which the respondents' statements were qualified. Analysis of the responses consisted of measuring their appearance in a given category.

\begin{tabular}{|c|c|}
\hline Question / stem & Analysed response categories \\
\hline $\begin{array}{l}\text { - Compare your company to any vehicle. } \\
\text {-What does the customer do in this vehicle? }\end{array}$ & $\begin{array}{l}\text { Attitude to the consumer and their importance } \\
\text { - The customer is a component of the vehicle/company } \\
\text { - The customer is outside the vehicle/company } \\
\text { - There is no customer } \\
\text { Focus on identification of customer needs } \\
\text { - Entrepreneur seeks contact with the customer (proactive) } \\
\text { - Entrepreneur is passive, the customer actively seeks contact with } \\
\text { him/her } \\
\text { - The customer evaluates the entrepreneur }\end{array}$ \\
\hline
\end{tabular}




\begin{tabular}{|c|c|}
\hline Question/stem & Analysed response categories \\
\hline & $\begin{array}{l}\text { Potential actions taken towards the customer } \\
\text { - Cooperation } \\
\text { - Battle } \\
\text { - Rivalry } \\
\text { - Tolerance of the customer's presence next to the company }\end{array}$ \\
\hline -Who else is with you in this vehicle? & $\begin{array}{l}\text { - The customer is a component of the vehicle/company } \\
\text { - The customer is outside the vehicle/company } \\
\text { - There is no customer }\end{array}$ \\
\hline - The most serious risk... & $\begin{array}{l}\text { - No customers, demand, sales, etc. } \\
\text { - Competition } \\
\text { - Financial problems } \\
\text { - Lack of knowledge and experience } \\
\text { - Psychological problems } \\
\text { - Other }\end{array}$ \\
\hline $\begin{array}{l}\text { - Factors hampering running of the } \\
\text { company.. }\end{array}$ & $\begin{array}{l}\text { - Customer } \\
\text { - Idea } \\
\text { - Competition } \\
\text { - Market } \\
\text { - Other }\end{array}$ \\
\hline $\begin{array}{l}\text { - In running a business what would help } \\
\qquad \text { me ... }\end{array}$ & $\begin{array}{l}\text { - Knowledge of the customer, market etc., idea } \\
\text { - Financial support } \\
\text { - Emotional Support } \\
\text { - Experience } \\
\text { - Knowledge } \\
\text { - Consultancy } \\
\text { - Other }\end{array}$ \\
\hline
\end{tabular}

Source: Own report

Table 1. Analysed categories of responses for the Metaphor Questionnaire and the Incomplete Sentences Questionnaire

The level of consumer orientation competency depended on whether and how many people gave diagnostic responses, i.e. belonging to the proper category. This information is included in Table 2.

The replies of the respondents divided into categories are presented in the following Tables. These show the percentage of responses that fall into a given category. In the group of students, due to the large number of them, only example answers are given. Readers interested in the full results may obtain these via email. On the other hand, all answers given by the entrepreneurs are quoted. 


\begin{tabular}{|c|c|c|c|}
\hline $\begin{array}{l}\text { Component of consumer } \\
\text { orientation competency }\end{array}$ & $\begin{array}{l}\text { Question from the } \\
\text { Metaphor Questionnaire } \\
\text { Version I and Version II }\end{array}$ & $\begin{array}{c}\text { Stem from the } \\
\text { Incomplete Sentences } \\
\text { Questionnaire }\end{array}$ & $\begin{array}{l}\text { Category of response } \\
\text { diagnostic for consumer } \\
\text { orientation competency }\end{array}$ \\
\hline $\begin{array}{c}\text { Attitude to the consumer and } \\
\text { their importance }\end{array}$ & $\begin{array}{l}\text { - Compare your company } \\
\text { to any vehicle. } \\
\text { - What does the consumer } \\
\text { do in this vehicle? } \\
\text { - Who else is with you in } \\
\text { this vehicle? }\end{array}$ & $\begin{array}{l}\text { - The most serious risk in } \\
\text { running your own } \\
\text { business... } \\
\text { - Factors hampering } \\
\text { running of the } \\
\text { company ... }\end{array}$ & $\begin{array}{l}\text { - The consumer is a } \\
\text { component of the vehicle/ } \\
\text { company } \\
\text { - No consumers, demand, } \\
\text { sales, etc. } \\
\text { - Consumer }\end{array}$ \\
\hline $\begin{array}{l}\text { Focus on identification of } \\
\text { consumer needs }\end{array}$ & $\begin{array}{l}\text {-What does the consumer } \\
\text { do in this vehicle? } \\
\text { - Who else is with you in } \\
\text { this vehicle? }\end{array}$ & - & $\begin{array}{l}\text { - Entrepreneur seeks contact } \\
\text { with the consumer (proactive) } \\
\text { - The consumer is a } \\
\text { component of the vehicle/ } \\
\text { company }\end{array}$ \\
\hline $\begin{array}{l}\text { Potential actions taken } \\
\text { towards the consumer }\end{array}$ & $\begin{array}{l}\text { - What does the consumer } \\
\text { do in this vehicle? }\end{array}$ & - & - Cooperation \\
\hline $\begin{array}{c}\text { Areas in which Support is } \\
\text { expected }\end{array}$ & - & $\begin{array}{l}\text { - In running a business } \\
\text { what would help me ... }\end{array}$ & $\begin{array}{l}\text { - Knowledge of the consumer, } \\
\text { market etc., idea }\end{array}$ \\
\hline
\end{tabular}

Source: Own report

Table 2. Categories of respondent answer diagnostic for consumer orientation competency

\section{Study results - Students}

The table below provides answers in Metaphor Questionnaire Version II and students planning and not planning to start their own business.

\begin{tabular}{|c|c|c|c|c|}
\hline \multirow{3}{*}{$\begin{array}{c}\text { Questions from the } \\
\text { questionnaire } \\
\text { Respondents' answers }\end{array}$} & \multicolumn{4}{|c|}{$\begin{array}{l}\text { Compare your company to any vehicle. } \\
\text { What does the customer do in this vehicle? }\end{array}$} \\
\hline & \multicolumn{2}{|c|}{$\%$ of responses } & \multicolumn{2}{|c|}{ Sample Answers } \\
\hline & $\begin{array}{c}\text { Expecting to start } \\
\text { their own } \\
\text { business }\end{array}$ & $\begin{array}{l}\text { Not expecting to } \\
\text { start their own } \\
\text { business }\end{array}$ & $\begin{array}{l}\text { Expecting to start their } \\
\text { own business }\end{array}$ & $\begin{array}{l}\text { Not expecting to start } \\
\text { their own business }\end{array}$ \\
\hline \multicolumn{5}{|c|}{ Attitude to the consumer and their importance } \\
\hline $\begin{array}{l}\text { The consumer is a } \\
\text { component of the } \\
\text { vehicle/company }\end{array}$ & 25 & 48 & $\begin{array}{l}\text { - The consumer sits at } \\
\text { the front of a bus on the } \\
\text { first seat } \\
\text { - is my pilot }\end{array}$ & $\begin{array}{l}\text { - the consumer is waiting } \\
\text { for a solution, trying to } \\
\text { offer their own solution, } \\
\text { and as a manager I listen } \\
\text { to it }\end{array}$ \\
\hline
\end{tabular}




\begin{tabular}{|c|c|c|c|c|}
\hline \multirow[t]{3}{*}{$\begin{array}{l}\text { Questions from the } \\
\text { questionnaire }\end{array}$} & \multicolumn{4}{|c|}{$\begin{array}{l}\text { Compare your company to any vehicle. } \\
\text { What does the customer do in this vehicle? }\end{array}$} \\
\hline & \multicolumn{2}{|c|}{$\%$ of responses } & \multicolumn{2}{|c|}{ Sample Answers } \\
\hline & $\begin{array}{c}\text { Expecting to start } \\
\text { their own } \\
\text { business }\end{array}$ & $\begin{array}{l}\text { Not expecting to } \\
\text { start their own } \\
\text { business }\end{array}$ & $\begin{array}{l}\text { Expecting to start their } \\
\text { own business }\end{array}$ & $\begin{array}{l}\text { Not expecting to start } \\
\text { their own business }\end{array}$ \\
\hline \multicolumn{5}{|c|}{ Attitude to the consumer and their importance } \\
\hline & & & & $\begin{array}{l}\text { - the consumer is the fuel } \\
\text { propelling the vehicle } \\
\text { (electricity) }\end{array}$ \\
\hline $\begin{array}{l}\text { The consumer is outside } \\
\text { the vehicle/company }\end{array}$ & 57 & 38 & $\begin{array}{l}\text { - may enter, receives } \\
\text { service, and leaves } \\
\text { - looks and admires }\end{array}$ & $\begin{array}{l}\text { - takes care of their own } \\
\text { affairs } \\
\text { - keeps close to the } \\
\text { rocket, may be in some } \\
\text { way related to it }\end{array}$ \\
\hline There is no consumer & 3 & 0 & $\begin{array}{l}\text { - there is no consumer } \\
\text { - there are no } \\
\text { customers }\end{array}$ & - \\
\hline No answer & 15 & 14 & - & - \\
\hline \multicolumn{5}{|c|}{ Focus on identification of customer needs } \\
\hline $\begin{array}{l}\text { Entrepreneur seeks } \\
\text { contact with the } \\
\text { customer (proactive) }\end{array}$ & 26 & 14 & $\begin{array}{l}\text { - rests, my f-16 will } \\
\text { take the product to } \\
\text { their home } \\
\text { - is my map and } \\
\text { policy; thanks to them I } \\
\text { will go further } \\
\text { - the consumer } \\
\text { determines what is } \\
\text { expected, what s/he } \\
\text { wants and receives } \\
\text { from the company } \\
\text { what he expected }\end{array}$ & $\begin{array}{l}\text { - chooses the route } \\
\text { - the customer is the fuel } \\
\text { propelling the vehicle } \\
\text { (electricity) } \\
\text { - sitting in the back seat } \\
\text { and not worrying about } \\
\text { anything because they are } \\
\text { informed about } \\
\text { everything directly and } \\
\text { we spare him/her almost } \\
\text { all tasks }\end{array}$ \\
\hline $\begin{array}{c}\text { Entrepreneur is passive, } \\
\text { the customer actively } \\
\text { seeks contact with } \\
\text { him/her }\end{array}$ & 34 & 62 & $\begin{array}{l}\text { - the customer stands } \\
\text { by the road and waits } \\
\text { for a suitable } \\
\text { entrepreneur - like } \\
\text { me :) } \\
\text { - runs after me }\end{array}$ & $\begin{array}{l}\text { - the customer comes for } \\
\text { advice, and receives it } \\
\text { - sitting in the car and } \\
\text { waits patiently } \\
\text { - uses the services of my } \\
\text { business }\end{array}$ \\
\hline $\begin{array}{c}\text { The customer evaluates } \\
\text { the entrepreneur }\end{array}$ & 21 & 24 & $\begin{array}{l}\text { - the customer is } \\
\text { satisfied with our } \\
\text { services }\end{array}$ & $\begin{array}{l}\text { - is smiling, talking with } \\
\text { us } \\
\text { - Rides on the back seat, } \\
\text { comfortably settled }\end{array}$ \\
\hline
\end{tabular}




\begin{tabular}{|c|c|c|c|c|}
\hline \multirow[t]{3}{*}{$\begin{array}{c}\text { Questions from the } \\
\text { questionnaire }\end{array}$} & \multicolumn{4}{|c|}{$\begin{array}{l}\text { Compare your company to any vehicle. } \\
\text { What does the customer do in this vehicle? }\end{array}$} \\
\hline & \multicolumn{2}{|c|}{$\%$ of responses } & \multicolumn{2}{|c|}{ Sample Answers } \\
\hline & $\begin{array}{c}\text { Expecting to start } \\
\text { their own } \\
\text { business }\end{array}$ & $\begin{array}{l}\text { Not expecting to } \\
\text { start their own } \\
\text { business }\end{array}$ & $\begin{array}{l}\text { Expecting to start their } \\
\text { own business }\end{array}$ & $\begin{array}{l}\text { Not expecting to start } \\
\text { their own business }\end{array}$ \\
\hline \multicolumn{5}{|c|}{ Attitude to the consumer and their importance } \\
\hline & & & $\begin{array}{l}\text { - is satisfied with the } \\
\text { company }\end{array}$ & \\
\hline No answer & 19 & 0 & & \\
\hline \multicolumn{5}{|c|}{ Potential actions taken towards the customer } \\
\hline Cooperation & 43 & 57 & $\begin{array}{l}\text { - sits in my plane as } \\
\text { a passenger, gets out } \\
\text { after finishing } \\
\text { cooperation } \\
\text { - is my support } \\
\text { - works with me for } \\
\text { our mutual benefit }\end{array}$ & $\begin{array}{l}\text { - is a passenger who uses } \\
\text { services } \\
\text { - the customer comes for } \\
\text { advice, and receives it }\end{array}$ \\
\hline Battle & 3 & 0 & $\begin{array}{l}\text { - is watching me, } \\
\text { waiting for an } \\
\text { opportunity, is } \\
\text { greedy } \\
\text { - the customer must } \\
\text { trust me and believe } \\
\text { that I will do } \\
\text { everything to keep } \\
\text { them happy }\end{array}$ & - \\
\hline Rivalry & 3 & 5 & $\begin{array}{l}\text { - talks to me and } \\
\text { listens to me } \\
\text { - there is no } \\
\text { consumer }\end{array}$ & $\begin{array}{l}\text { - takes care of their own } \\
\text { affairs }\end{array}$ \\
\hline $\begin{array}{l}\text { Tolerance of the } \\
\text { customer's presence next } \\
\text { to the company }\end{array}$ & 36 & 38 & $\begin{array}{l}\text { - is waiting for an } \\
\text { opportunity } \\
\text { - wants to drive the } \\
\text { Ferrari }\end{array}$ & $\begin{array}{l}\text { - sits comfortably in the } \\
\text { compartment feeling } \\
\text { comfort and safety } \\
\text { - sits next to me }\end{array}$ \\
\hline No answer & 15 & 0 & & \\
\hline
\end{tabular}

Source: Own calculations based on data from studies

Table 3. Summary of student responses in Metaphor Questionnaire Version II

The first element, consisting of a COC in accordance with the adopted approach assigns great importance to the customer. This should be found in the metaphors provided by the respond- 
ents. In fact, it was found that only $25 \%$ of respondents identify the customer as an element of the vehicle representing the company. The vast majority $-57 \%$ - locate the consumer outside the company, and 3\% believe that they are not present at all.

The cited responses "the consumer sits in the front of the bus on the first seat" and "is my pilot" are the essence of thinking in terms of orientation towards the customer, who is a major factor in the company's operation on the market. As is evident, most of the respondents do not share this point of view, which is a worrying sign. The result of the group not planning to start their own business is interesting because there the proportions are reversed, as if they were more aware of the importance of the customer. Due to the small number of respondents from this group, they cannot be directly compared, but this is certainly an interesting result to be investigated further.

The next element of COC is the attitude to recognising customer needs. In this case, the diagnostic response is the one showing that the entrepreneur is proactively seeking contact with the customer and how to meet their needs. In the planning group this approach is shown by $26 \%$ of respondents, which may coincide with the answers on the importance of the customer. Dominating, however, is the attitude of passivity towards the consumer (34\%). In their view, the consumer him/herself takes the initiative to make contact with the entrepreneur. In conjunction with the replies of the categories on simply tolerating the presence of the customer, more than half (55\%) of the students obtained a result showing a very low level of COC.

At the same time there are negative signals, demonstrating the fact that students who are planning to start a business have unrealistic expectations and wishful thinking, for example, that the customer will wait or even run after their company. Meanwhile, the realities of today's market are quite different. Using the terminology of cognitive psychology, we can conclude that the cognitive schemata and scripts held by respondents and relating to the client and how to run a company are clearly inappropriate to what is happening in the real world of business.

Slightly less disturbing are the answers concerning the potential actions taken towards the customer. $43 \%$ of respondents stated an approach requiring cooperation with the customer. This is not, however, entirely satisfactory, because of the fact that $36 \%$ of respondents simply tolerate the presence of the customer, showing no initiative to establish relations with them.

We can thus conclude that even if respondents indicate the importance of the customer in their responses, they feel as if they have no effect on his/her behaviour and do not plan to conduct any informed, purposeful activity addressed to him/her. They do not think they can control the relationship with the customer, as if they were simply stuck with what s/he does. This is particularly visible in the group of respondents not planning to start a business, and perhaps therefore will not take that decision. This is an area for closer examination and potentially targeted educational impact.

Complementing the above considerations are the data obtained in the Incomplete Sentences Questionnaire, whose results are shown in the table below. 


\begin{tabular}{|c|c|c|c|c|}
\hline \multirow[b]{3}{*}{ Respondents' answers } & \multicolumn{4}{|c|}{ The most serious risk in running your own business... } \\
\hline & \multicolumn{2}{|c|}{$\%$ of responses } & \multicolumn{2}{|c|}{ Sample Answers } \\
\hline & $\begin{array}{c}\text { Expecting to start } \\
\text { their own } \\
\text { business }\end{array}$ & $\begin{array}{l}\text { Not expecting to } \\
\text { start their own } \\
\text { business }\end{array}$ & $\begin{array}{l}\text { Expecting to start their own } \\
\text { business }\end{array}$ & $\begin{array}{l}\text { Not expecting to start } \\
\text { their own business }\end{array}$ \\
\hline $\begin{array}{l}\text { No customers, } \\
\text { demand, sales }\end{array}$ & 17 & 22 & $\begin{array}{l}\text { - There are no customers } \\
\text { - lack of customer interest } \\
\text { - decreasing demand for a } \\
\text { given good that we want to } \\
\text { sell }\end{array}$ & $\begin{array}{l}\text { - failure to accept a } \\
\text { given good or service by } \\
\text { the market } \\
\text { - poor adaptation of the } \\
\text { goods on offer to market } \\
\text { needs }\end{array}$ \\
\hline Competition & 28 & 26 & $\begin{array}{l}\text { - Competition } \\
\text { - Competition and the } \\
\text { market you're in } \\
\text { - high risk from aggressive } \\
\text { competition }\end{array}$ & $\begin{array}{l}\text { - competition, which } \\
\text { could "finish" my } \\
\text { company }\end{array}$ \\
\hline Financial problems & 21 & 22 & $\begin{array}{l}\text { - bankruptcy } \\
\text { - incurring debts } \\
\text { - lack of funding for } \\
\text { various projects, services or } \\
\text { goods }\end{array}$ & $\begin{array}{l}\text { - bankruptcy and debts, } \\
\text { loans } \\
\text { - lack of liquidity and } \\
\text { customers who do not } \\
\text { pay }\end{array}$ \\
\hline $\begin{array}{l}\text { Lack of knowledge } \\
\text { and experience }\end{array}$ & 5 & 4 & $\begin{array}{l}\text { - lack of "business" skills } \\
\text { • incompetence and lack of } \\
\text { experience }\end{array}$ & $\begin{array}{l}\text { - inability to take control } \\
\text { over workers and the } \\
\text { quality of selection }\end{array}$ \\
\hline $\begin{array}{c}\text { Psychological } \\
\text { problems }\end{array}$ & 12 & 9 & $\begin{array}{l}\text { - fear } \\
\text { - lack of motivation } \\
\text { - greed for excessive profits }\end{array}$ & - coping with stress \\
\hline Others & 13 & 17 & $\begin{array}{l}\text { - Political parties that } \\
\text { approve "strange" laws } \\
\text { hostile to companies } \\
\text { - environmental variables }\end{array}$ & - economic crisis \\
\hline
\end{tabular}

Source: Own calculations based on data from studies

Table 4. Student responses in the Incomplete Sentences Questionnaire. The most serious risk in running your own business..

Respondents were able to indicate any possible risks occurring to them that may arise in the course of business and, therefore, their answers do not add up to $100 \%$.

The diagnostic response for COC - that the most serious threat in running your own business is the lack of customers, etc. - was given by only $17 \%$ of those planning to start a company and 
was in third place. First place was taken by competition (28\%) and second financial problems (21\%).

In combination with the fact that they are passive in meeting customer needs, it can be assumed that the respondents do not fully understand the rules of company operation. For example, that the customer should be the main objective of combating competition and providing funds.

It is also interesting that the percentage distribution of responses in both groups is similar, that is, plans to start your own business are not intrinsically linked to an understanding of the rules of functioning on the market. This is another indication that a properly conducted process of entrepreneurial learning may be very important. It is also worth noting that $12 \%$ of respondents identified psychological problems as a threat to running a company.

\begin{tabular}{|c|c|c|c|c|}
\hline \multirow[b]{3}{*}{ Respondents' answers } & \multicolumn{4}{|c|}{ Factors hampering running of the company ... } \\
\hline & \multicolumn{2}{|c|}{$\%$ of responses } & \multicolumn{2}{|c|}{ Sample Answers } \\
\hline & $\begin{array}{c}\text { Expecting to start } \\
\text { their own } \\
\text { business }\end{array}$ & $\begin{array}{l}\text { Not expecting to } \\
\text { start their own } \\
\text { business }\end{array}$ & $\begin{array}{l}\text { Expecting to start their own } \\
\text { business }\end{array}$ & $\begin{array}{l}\text { Not expecting to start their } \\
\text { own business }\end{array}$ \\
\hline Customer & 7 & 0 & $\begin{array}{l}\text { - stress; crisis; lack of } \\
\text { customers or interest on the } \\
\text { market } \\
\text { - high costs; crowded } \\
\text { markets; difficulties in } \\
\text { reaching the customer }\end{array}$ & - \\
\hline Idea & 4 & 23 & $\begin{array}{l}\text { - big responsibility; } \\
\text { necessary start-up capital; a } \\
\text { lot of competition (the } \\
\text { concept must be unique) } \\
\text { - competition; capital (too } \\
\text { low); lack of ideas for your } \\
\text { company }\end{array}$ & $\begin{array}{l}\text { - Lack of capital to start a } \\
\text { business; lack of ideas; lack } \\
\text { of competence and skills } \\
\text { - bureaucracy; lack of ideas } \\
\text { for an effective enterprise }\end{array}$ \\
\hline Competition & 21 & 23 & $\begin{array}{l}\text { - a lot of competition } \\
\text { - competition; time- } \\
\text { consuming; responsibility }\end{array}$ & $\begin{array}{l}\text { - high responsibility; } \\
\text { possible strong competition; } \\
\text { a significant risk that we } \\
\text { will fail } \\
\text { - dishonest employees, } \\
\text { competition, etc.; our final } \\
\text { decisions may prove to be } \\
\text { inaccurate; bureaucracy }\end{array}$ \\
\hline
\end{tabular}




\begin{tabular}{|c|c|c|c|c|}
\hline Question from the & & Factors ham & pering running of the compa & any ... \\
\hline \multirow[b]{2}{*}{ Respondents' answers } & \multicolumn{2}{|c|}{$\%$ of responses } & \multicolumn{2}{|c|}{ Sample Answers } \\
\hline & $\begin{array}{c}\text { Expecting to start } \\
\text { their own } \\
\text { business }\end{array}$ & $\begin{array}{c}\text { Not expecting to } \\
\text { start their own } \\
\text { business }\end{array}$ & $\begin{array}{l}\text { Expecting to start their own } \\
\text { business }\end{array}$ & $\begin{array}{l}\text { Not expecting to start their } \\
\text { own business }\end{array}$ \\
\hline Market & 16 & 0 & $\begin{array}{l}\text { - high costs; crowded } \\
\text { markets; difficulties in } \\
\text { reaching the customer } \\
\text { - constantly changing } \\
\text { market conditions; the need } \\
\text { for continuous } \\
\text { modernisation }\end{array}$ & - \\
\hline other & 53 & 23 & $\begin{array}{l}\text { - high cost of living; a lot of } \\
\text { responsibilities; lack of } \\
\text { funds } \\
\text { - Full responsibility for the } \\
\text { business; risk; stress, a lot } \\
\text { of work and responsibilities }\end{array}$ & $\begin{array}{l}\text { - Responsibility, risk, lack } \\
\text { of stability } \\
\text { - Too low capital; many } \\
\text { formalities; fear of risk }\end{array}$ \\
\hline
\end{tabular}

Source: Own calculations based on data from studies

Table 5. Student responses in the Incomplete Sentences Questionnaire Factors hampering running of the company...

In the case of the factors hampering running the company, respondents could also indicate several factors and therefore the responses do not add up to one hundred percent. Only $7 \%$ of respondents explicitly point to the customer as a source of difficulty. Competition was indicated by $21 \%$, and the market by $16 \%$. Over half (53\%) of the respondents focused on factors not directly related to the customer and the market.

The complement of this information is investigation of what they need to conduct business. In addition to COC diagnosis, this may also be an indication for entrepreneurship education.

The need for awareness of the customer, the market, concept and knowledge is indicated by only $5 \%$ of respondents, which should be a clearly worrying signal for education. The more so that most of both those planning (22\%) and not planning $(24 \%)$ to start a business indicated that consultancy would help them, most often understood as support from someone experienced in conducting business. Among those planning to start a company, the second need was for financial support (20\%), followed by emotional support (17\%), and a lack of experience $16 \%$. Consultancy is actually a type of substantive support, but also psychological. Perhaps those respondents focused on their own needs have difficulty focusing on the customer. 


\begin{tabular}{|c|c|c|c|c|}
\hline \multirow{3}{*}{$\begin{array}{c}\text { Question from the } \\
\text { questionnaire } \\
\\
\text { Respondents' } \\
\text { answers }\end{array}$} & \multicolumn{4}{|c|}{ In running a business what would help me ... } \\
\hline & \multicolumn{2}{|c|}{$\%$ of responses } & \multicolumn{2}{|c|}{ Sample Answers } \\
\hline & $\begin{array}{c}\text { Expecting to start } \\
\text { their own } \\
\text { business }\end{array}$ & $\begin{array}{c}\text { Not expecting to } \\
\text { start their own } \\
\text { business }\end{array}$ & $\begin{array}{l}\text { Expecting to start their } \\
\text { own business }\end{array}$ & $\begin{array}{l}\text { Not expecting to start their } \\
\text { own business }\end{array}$ \\
\hline $\begin{array}{l}\text { Knowledge of the } \\
\text { customer, market etc., } \\
\text { idea }\end{array}$ & 5 & 5 & $\begin{array}{l}\text { - thorough analysis of the } \\
\text { environment and the } \\
\text { market in which I want to } \\
\text { work } \\
\text { - prior knowledge of } \\
\text { potential customers }\end{array}$ & $\begin{array}{l}\text { - knowledge of the market } \\
\text { and competition }\end{array}$ \\
\hline Financial support & 20 & 14 & $\begin{array}{l}\text { - having unlimited capital } \\
\text { - lots of money }\end{array}$ & - good financial security \\
\hline Emotional Support & 17 & 19 & $\begin{array}{l}\text { - belief in my own abilities } \\
\text { and greater self-confidence } \\
\text { - family support } \\
\text { - having people who } \\
\text { would share the } \\
\text { responsibility with me and } \\
\text { help me decide }\end{array}$ & $\begin{array}{l}\text { - support of brothers, and } \\
\text { especially parents, and } \\
\text { numerous training courses } \\
\text { - trusted friends }\end{array}$ \\
\hline Experience & 16 & 10 & $\begin{array}{l}\text { - experience acquired in } \\
\text { previous jobs and } \\
\text { experienced staff } \\
\text { - the assistance of an } \\
\text { experienced } \\
\text { businessperson }\end{array}$ & $\begin{array}{l}\text { - experience gained in a } \\
\text { company with a similar } \\
\text { business }\end{array}$ \\
\hline Knowledge & 5 & 19 & $\begin{array}{l}\text { - training courses on how } \\
\text { to run your own business }\end{array}$ & $\begin{array}{l}\text { - acquiring knowledge of } \\
\text { how to run a business }\end{array}$ \\
\hline Consultancy & 22 & 24 & - expert support & $\begin{array}{l}\text { - help from someone with } \\
\text { experience } \\
\text { - transfer of knowledge } \\
\text { from other entrepreneurs }\end{array}$ \\
\hline Others & 15 & 24 & - skilled workers & $\begin{array}{l}\text { - obtaining good and } \\
\text { trusted employees }\end{array}$ \\
\hline
\end{tabular}

Source: Own calculations based on data from studies

Table 6. Student responses in the Incomplete Sentences Questionnaire In running a business what would help me... 


\section{Study results - Entrepreneurs}

It is worth taking a close look at the results obtained from the group of entrepreneurs, because thanks to their participation in the project they found themselves in approximately the situation in which the students would like to see themselves. They have a business idea, and they have received financial and technical support and advice. The study tested their responses in terms of the level of COC in the extended version of Metaphor Questionnaire Version I. The results are given in the table below.

\begin{tabular}{|c|c|c|}
\hline $\begin{array}{l}\text { Question from the } \\
\text { questionnaire }\end{array}$ & $\%$ of responses & Compare your company to a vehicle \\
\hline $\begin{array}{l}\text { The consumer is a } \\
\text { component of the vehicle/ } \\
\text { company }\end{array}$ & 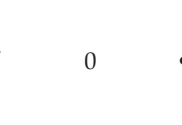 & - There were no comparisons in this category \\
\hline $\begin{array}{l}\text { The consumer is } \\
\text { mentioned, but outside } \\
\text { the vehicle / company }\end{array}$ & 14 & $\begin{array}{l}\text { - I find it hard to compare it to a vehicle. The company will be shaped as a } \\
\text { "virtual organisation". Access to all resources via the Internet from } \\
\text { anywhere. A Call Centre to serve customers from anywhere } \\
\text { - A limousine - every employee, even the chauffeur and the client, is } \\
\text { proud to cooperate with my company, there is nothing to be ashamed of, } \\
\text { they are well treated, happy, the workplace is comfortable and welcomes } \\
\text { creative and productive work or cooperation with the client } \\
\text { - an ambulance - quick reaction or fire engine for customer needs }\end{array}$ \\
\hline There is no consumer & 86 & $\begin{array}{l}\text { - better make of car with good acceleration, able to drive in difficult } \\
\text { conditions } \\
\text { - a floating drilling platform - we're looking for places, we penetrate a } \\
\text { topic, work and derive benefits; if necessary there is the option for } \\
\text { extension or expansion into another area } \\
\text { - the most modern fighter or NASA aircraft - modernity, speed - work on } \\
\text { self-realisation - or continuous self-improvement } \\
\text { - bike or tricycle } \\
\text { - sailing boat } \\
\text { - spacecraft or space shuttle } \\
\text { - black Seat - safe, dynamic, classy } \\
\text { - Range Rover Sport, fast, big, safe, all-terrain, always reaches the } \\
\text { destination } \\
\text { - Jeep - useful, convenient } \\
\text { - Sledge - Simple but probably difficult to come up with simple ideas. } \\
\text { (Relatively) little need - only a "frame" and manuals (advertising, } \\
\text { promotion) and you can drive at will. Even though you have to reach the } \\
\text { top by foot, sledges are reliable. } \\
\text { - a solar energy vehicle, something new }\end{array}$ \\
\hline
\end{tabular}




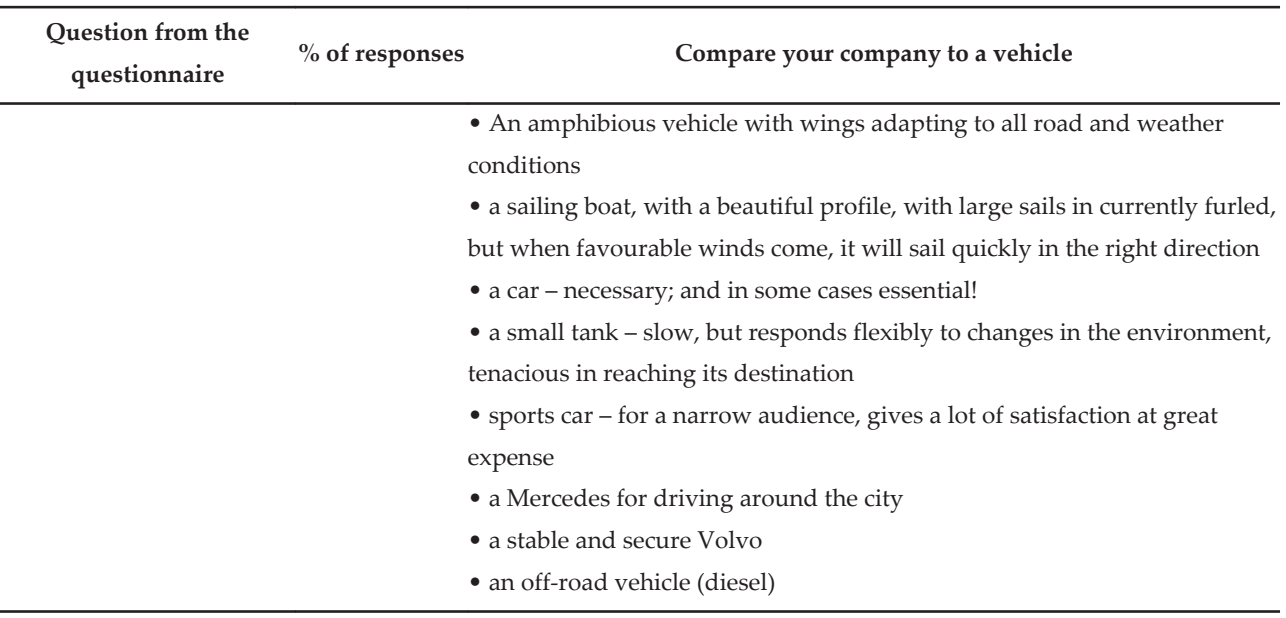

Source: Own calculations based on data from studies

Table 7. Entrepreneur responses to Metaphor Questionnaire Version I

The customer as part of the company does not appear in any of the entrepreneur responses, and only $14 \%$ cited it outside the company. Other answers do not allude directly to the customer. This is surprising when you take into account the fact that these are people who have started the process of running their own business. The analysis of responses to the question "What does the customer do in this vehicle?" provides more information on this topic.

\begin{tabular}{c}
\hline $\begin{array}{c}\text { Question from the } \\
\text { questionnaire }\end{array} \quad$ What does the customer do in this vehicle? \\
\hline
\end{tabular}

\begin{tabular}{|c|c|c|}
\hline $\begin{array}{l}\text { Entrepreneur seeks } \\
\text { contact with the } \\
\text { customer }\end{array}$ & 27 & $\begin{array}{l}\text { - I am looking for them in this forest, I drive our other vehicles, we greet } \\
\text { each other, we talk } \\
\text { - is a passenger } \\
\text { - I invite him on a cruise full of beautiful impressions } \\
\text { - he is sitting next to me and amiably talking with me } \\
\text { - he is resting, drinking cocktails, spending a good time as he pleases, wish } \\
\text { fulfilment } \\
\text { - sits next to me }\end{array}$ \\
\hline $\begin{array}{l}\text { Entrepreneur is passive, } \\
\text { the customer actively } \\
\text { seeks contact with } \\
\text { him/her }\end{array}$ & 46 & $\begin{array}{l}\text { - arrives, pays and receives the goods and smiles at the same time } \\
\text { - chooses } \\
\text { - waits for my arrival, always on time! } \\
\text { - the client is waiting for us. They are calm, because they know that soon } \\
\text { we will arrive and solve their problem } \\
\text { - they wait for me and do not even expect that they seriously need what I } \\
\text { have for him. And we (me first) tell him this }\end{array}$ \\
\hline
\end{tabular}




\begin{tabular}{|c|c|c|}
\hline $\begin{array}{l}\text { Question from the } \\
\text { questionnaire }\end{array}$ & $\%$ of responses & What does the customer do in this vehicle? \\
\hline & & $\begin{array}{l}\text { - draws from my work } \\
\text { - enjoys the pleasure that comes from travelling in this vehicle } \\
\text { - the customer orders services } \\
\text { - is waiting for my arrival } \\
\text { - is satisfied and pleased that he is leaving me his money - is satisfied in } \\
\text { the long term }\end{array}$ \\
\hline $\begin{array}{c}\text { The customer remains } \\
\text { on the outside and } \\
\text { evaluates the } \\
\text { entrepreneur }\end{array}$ & 27 & $\begin{array}{l}\text { - assesses how I am driving } \\
\text { - feels relaxed and is happy to tell others about this place } \\
\text { - the customer watches as I drive } \\
\text { - looks at the vehicle with admiration } \\
\text { - is enjoying himself } \\
\text { - observes the behaviour of my tank with caution (but is fascinated by it) }\end{array}$ \\
\hline
\end{tabular}

Source: Own calculations based on data from the studies

Table 8. Entrepreneur responses to Metaphor Questionnaire Version I

In this group, the largest number of respondents (46\%) displays an attitude of passively waiting for customer response. In this respect, they do not differ from the students planning to set up a business, while demonstrating the unrealistic attitude that the customer is waiting for them. In conjunction with the $27 \%$ of the group for whom the customer only assesses their operations, this gives a worrying signal that the studied individuals are not sufficiently customer-oriented. Only $27 \%$ of respondents could be classified as showing that the entrepreneur is set to proactively seek contact with the customer. This is definitely not enough to be confident that the majority in this group will be able to use the support offered them and effectively keep their company on the market, and thus that the funds allocated to the project will be used optimally. The analysis of the responses given below provides some clues as to the causes of this situation.

Only $19 \%$ of respondents listed the customer as someone who is with them in the vehicle $(14 \%)$ or outside the vehicle (5\%). The remaining $81 \%$ indicate other people, among whom the dominant group are by far family members or friends. It is worth looking closer at the fact that within the company there are close people, relations with whom are friendly or family. This suggests that respondents did not identify the rules of company operation based on market principles. They see it more as a community. According to Bolesta-Kukułka [42] the specific nature of this community is that the purpose of its existence is collective co-existence, to overcome the difficulties and obstacles that threaten survival, as is the case in the family. Among the members of the community there is a strong psychological bond and continuous and permanent relationships of obligation and entitlement. Whereas a profit-oriented company market should have the characteristics of an organisation that, as Bolesta-Kukułka writes [43] exists to implement goals already decided by someone else. The relationships existing within it are formalised and objectivised and not the result of mutual agreement and adapta- 
tion. If the entrepreneur treats the company as a way of meeting the needs of the family, they may lose the pro-customer perspective. This is because the customer is shifted to the wayside, external, and cognitively it is virtually impossible to focus on their needs. They are an external instrument in the "business as second family home". This misunderstanding of the rules of company operation, confusing them with communities, may be the cause of non-pro-effective decision-making and contribute to the loss of market position, even in the possession of professional knowledge in the field of entrepreneurship.

\begin{tabular}{|c|c|c|}
\hline $\begin{array}{l}\text { Question from the } \\
\text { questionnaire }\end{array}$ & $\%$ of responses & Who else is with you in this vehicle? \\
\hline $\begin{array}{l}\text { The customer is a } \\
\text { component of the vehicle/ } \\
\text { company }\end{array}$ & 14 & $\begin{array}{l}\text { - collaborators, customers, employees, friends, people, businesses which } \\
\text { support or build the developing market } \\
\text { - my customers } \\
\text { - Myself, employees, customers, not family just to be safe - an accident can } \\
\text { always happen even in the best car }\end{array}$ \\
\hline $\begin{array}{l}\text { The customer is } \\
\text { mentioned, but outside } \\
\text { the vehicle / company }\end{array}$ & 5 & $\begin{array}{l}\text { - Employees who are responsible for customer contact - sales, } \\
\text { implementation }\end{array}$ \\
\hline There is no customer & 81 & $\begin{array}{l}\text { - my loved ones and others unknown to me } \\
\text { - myself + employees } \\
\text { - my husband, son and dog } \\
\text { - a large number of interested people unknown to me } \\
\text { - someone to hold the tackle or lines } \\
\text { - my partner } \\
\text { - my employees! } \\
\text { - my co-workers or a cohesive team of several people } \\
\text { - a friend } \\
\text { - my boyfriend Adam, brother, dad, mum and a whole sledgeful joins us } \\
\text { - my acquaintances who run their own businesses } \\
\text { - the A Team - a proven team of trusted people } \\
\text { - I want to be the cox, and the passengers will be my family } \\
\text { - people who are friendly towards me } \\
\text { - family plus friends } \\
\text { - my family } \\
\text { - my co-workers } \\
\text { - no answer }\end{array}$ \\
\hline
\end{tabular}


If this is the belief of those who participate in business schools, and the results clearly show that it is, this might be one of the sources of inefficiency in the teaching methods. With such a belief as to the reasons for the existence of a company, there is no way that formal knowledge can be used properly in the course of business activity. Candidates for entrepreneurs must therefore learn to think in terms of the market and, in accordance with its rules, modify their beliefs and ideas. Attempts to transfer formal knowledge alone may end up in the fact that it will be absorbed automatically and incorrectly applied.

J.C. Sánchez consistently suggests that "the instructors (academics, lecturers, and trainers) should receive training not only in how to teach entrepreneurship but also in how to change "hearts and minds". [14]

\section{Consumer orientation competency level}

Generally, the COC level among the students who are planning to start a business and entrepreneurs should be assessed as low and not predictive that their entrepreneurial activity will help them to remain on the market. In the responses they provided in these projection tests, the customer is very rarely mentioned spontaneously. According to the approach adopted, this is an indicator of low awareness of the consumer's importance in the functioning of the company. With regard to recognising needs, the respondents strongly reveal an attitude of passivity towards the customer. They display no bias towards having a conscious, deliberate influence on him/her. At the same time, symptoms of wishful thinking may be observed, expressed by the fact that the customer will wait for the company and will be delighted with it. It is positive that they have a collaborative attitude, but in combination with other responses this does not seem credible. Complementing this is the fact that a small group of respondents reported the need for expertise and Support in attracting customers. In contrast they require a good of consultancy from experienced people, and financial and emotional Support.

The research also presents one more observation that is important from the point of view of entrepreneurship. Specifically, that there are indications of the fact that some candidates for entrepreneurs confuse the market organisation of a company with a community. They have a misconception about the purpose of a company and the rules by which it is directed by the market. This limits the capability to adopt a customer orientation.

To sum up the whole, it should be noted that the vast majority of respondents, according to the criteria, have a low level of consumer orientation competency, which may restrict their business success. Since all were participants in business schools, it is worth seeing how it happens that the educational process has not changed their non-proeffective beliefs and ideas.

Confirming what J.C. Sánchez says that "not only training in the knowledge and resources needed for starting a business, as traditionally considered. Training in entrepreneurial competencies implicitly entails an inspirational component. Inspiration is what gives rise to attitude and intention, and increases the students' interest in trying out an entrepreneurial career." [14] 


\section{Conclusion}

The data obtained provide some evidence for a possible improvement in the process of entrepreneurial education. They show that in order to teach it, ideas and beliefs must be disclosed, discussed, and undergo informed modification, and that formal knowledge must be provided on this basis. According to Morgan "the individual responds to his/her perception of the situation in which s/he finds him/herself. Through the metaphors we can reach this perception, identify it, and then we can modify it. This will then be reflected in a real change in the way people act." [44]

The diagnostic approach applied may be used in the course of learning. The teacher can ask the participants to complete the projection questionnaires presented in this paper, and then discuss the content contained therein jointly with them. It is also possible to use the methods applied in marketing research, such as personification, animalisation, or collage.

The purpose of education is to teach business thinking and a perception of the world in terms of market rules. Only on this basis can information and tools of company management be provided that will be applied on the basis of pro-effectiveness reasons and this will help to make a profit. Entrepreneurs need to know why they are using these tools, because their work is not activity reconstructed in accordance with prescribed procedures, but a continuous search for relevant solutions to a changing situation.

With respect to the research process, it is probably worth checking the results obtained using other diagnostic techniques. Metaphorical statements should not be regarded as constituting a fully adequate picture, but as a signal that it is worthwhile to look more closely at the issues identified. However, we can assume that if someone metaphorically describing reality as s/he sees it does not include certain elements, these are not important to him/her, and s/he will not be guided by them in their decisions.

Much could be made also by the analysis of the responses of individuals. It would also be interesting to carry out this research in groups that are different in terms of motivation by which they were guided in starting a company. The resulting material may also be an inspiration for further research, for example, on the relationship to competition. It seems significant and should be further checked what the respondents are thinking of saying that they need counselling and emotional support, with little indication of the demand for knowledge, which for education is particularly disturbing.

\section{Author details}

\section{Anna Pawłowska*}

Address all correspondence to: annap@wz.uw.edu.pl

Department of Organizational Sociology, Faculty of Management, University of Warsaw, Warsaw, Poland 


\section{References}

[1] The European Commision Press releases database http://europa.eu/rapid/press-release_IP-12-1233_pl.htm

[2] Matlay H. The impact of entrepreneurship education on entrepreneurial outcomes. Journal of Small Business and Enterprise Development 2008; 15 (1) pp. 382-396.

[3] Ministry of Infrastructure and Development http://www.mir.gov.pl/fundusze/ Fundusze_Europejskie_2014_2020/Documents/PO_WER_08012014.pdf

[4] in: Matlay H. The impact of entrepreneurship education on entrepreneurial outcomes. Journal of Small Business and Enterprise Development 2008; 15 (1) pp. 382-396.

[5] Kirby, D. Entrepreneurship education: can business schools meet the challenge?. Education+Training 2004; 46 (8/9), pp. 510-2.

[6] Polish Agency for Enterprise Development http://en.parp.gov.pl)

[7] Nobel, C. Why companies fail-and how their founders can bounce back. HBS Working Knowledge 2011, March 7 cyt. za: Gudmundsson, S.V., Lechner C., Cognitive biases, organization, and entrepreneurial firm survival. European Management Journal 2013; 31, pp. 278- 294.

[8] Raport of Eurydice "Entrepreneurship Education at School in Europe. National Strategies, Curricula and Learning Outcomes" March 2012 http://eacea.ec.europa.eu/ education/eurydice/documents/thematic_reports/135en.pdf

[9] Wach K. Kształtowanie postaw przedsiębiorczych w programach nauczania. Stan obecny i proponowane kierunki zmian. Conference of University of Economics in Katowice: Shaping entrepreneurial attitudes versus education of economics; Jun 2007 http://fundacja.edu.pl/przedsiebiorczosc/index.php?DOC=program

[10] Report of European Commission Enterprise and Industry Directorate-General "Entrepreneurship in higher education, especially in non-business studies" March 2008 http://ec.europa.eu/enterprise/policies/sme/files/support_measures/training_education/entr_highed_en.pdf

[11] Gajewski Z. Vice-General Manager of the Polish Confederation of Private Employers Lewiatan http://rynekpracy.org/wiadomosc/764239.html; April 2012

[12] Mitra, J., Matlay, H. Entrepreneurial and vocational education and training: lessons from Eastern and Central Europe. Industry and Higher Education 2004; 18 (1), pp. 53-69.

[13] Hansemark, O.C. Reed for achievement, locus of control and the prediction of business start-ups: A longitudinal study. Journal of Economic Psychology 2002; 24, pp. 301-319. 
[14] Sánchez J.C. The Impact of an Entrepreneurship Education Program on Entrepreneurial Competencies and Intention. Journal of Small Business Management 2013; 51(3), pp. 447-465 doi: 10.1111/jsbm.12025

[15] Rumelhart, D.E. Schematy - cegiełki poznania. In: Chlewiński Z. (ed.) Psychologia poznawcza w ostatnich trzech dekadach. Gdańsk: GWP; 2007, pp.431-455

[16] Strelau J., Doliński D. Psychologia. Podręcznik akademicki. Gdańsk: GWP; 2008.

[17] Koellinger, P., Minniti M., Schade Ch. "I think I can, I think I can": overconfidence and entrepreneurial behavior. Journal of Economic Psychology 2007; 28, pp. 502-527.

[18] Zaleśkiewicz, T. Przedsiębiorczość i podejmowanie ryzyka. In: Tyszka, T. (ed.) Psychologia ekonomiczna. Gdańsk: GWP; 2004, pp. 303-326

[19] in: Gudmundsson, S.V., Lechner C., Cognitive biases, organization, and entrepreneurial firm survival. European Management Journal 2013; 31, pp. 278- 294.

[20] Haynie J. M., Shepherd D., Mosakowski E., Earley P.C. A situated metacognitive model of the entrepreneurial mindset. Journal of Business Venturing 2010; 25 pp. 217-229.

[21] Bajcar B., Borkowska A., Czerw A., Gąsiorowska A., Nosal Cz. S. Psychologia preferencji i zainteresowań zawodowych. Przegląd teorii i metod, Warszawa: MPiPS Departament Rynku Pracy; 2006.

[22] Trzebiński J. Reprezentacje skryptopodobne jako formy ukrytych teorii osobowości, in: Jarymowicz J., Smoleńska Z., (ed.) Poznawcze regulatory funkcjonowania społecznego, Warszawa: Wydawnictwo Polskiej Akademii Nauk; 1983, p. 56.

[23] Reykowski J. Osobowość wobec przemian społecznych i technologicznych - szkic problematyki, in: Jarymowicz J., Smoleńska Z. (ed.) Poznawcze regulatory funkcjonowania społecznego, Warszawa: Wydawnictwo Polskiej Akademii Nauk; 1983, p. 229.

[24] Goffman, E. Człowiek w teatrze życia codziennego. Warszawa: PIW; 1981.

[25] Hofstede, G. Kultury i organizacje, Warszawa: PWE; 1998.

[26] Glinka B. Kulturowe uwarunkowania przedsiębiorczości. Warszawa: PWE; 2008

[27] Wickham P. A. Strategic entrepreneurship. Pearson Education, Limited; 2004

[28] Tajeddini K., Elg K., Trueman M. Efficiency and effectiveness of small retailers: The role of customer and entrepreneurial orientation. Journal of Retailing and Consumer Services 2013; 20 pp. 453-462.

[29] Morgan G. Wyobraźnia organizacyjna. Warszawa: PWN; 2002, p. 6

[30] Kirby, D. Entrepreneurship education: can business schools meet the challenge? Education+Training 2004; 46 (8/9), pp. 514. 
[31] Asikhia O. Customer Orientation and Firm Performance among Nigerian Small and Medium Scale Businesses. International Journal of Marketing Studies 2010, 2 (1), pp. 197-212

[32] Sęk, H. Teoretyczne podstawy metod projekcyjnych, in: Sęk, H. (ed.) Metody projekcyjne. Tradycja i współczesność. Poznań: Wydawnictwo UAM; 1984, p. 5

[33] Kowalik, S. Werbalne techniki projekcyjne, in: Sęk, H. (ed.) Metody projekcyjne. Tradycja i współczesność, Poznań: Wydawnictwo UAM; 1984, p. 91

[34] Stemplewska-Żakowicz K. Wprowadzenie, in: Stemplewska-Żakowicz K. (ed.), Nowe spojrzenia na Test Niedokończonych Zdań J.B. Rottera. Interpretacja jakościowa, Warszawa: Pracownia Testów Psychologicznych PTP; 1998, p. 14

[35] Maison, D. Zogniskowane wywiady grupowe: jakościowa metoda badań marketingowych, Warszawa: Wydawnictwo Naukowe PWN; 200, p. 30

[36] Morgan G. Obrazy organizacji. Warszawa: Wydawnictwo Naukowe PWN; 1997, p. 231

[37] Lakoff G., Johnson M. Metafory w naszym życiu, Warszawa: PIW; 1988, p.7

[38] Lilienfeld, S.D., Wood, J.M., Garb, H.N. Status naukowy technik projekcyjnych, Kraków: Wyd. UJ; 2002.

[39] Pawłowska A. Projection methods in diagnosing an individual's cognitive map of occupations. in: Mróz B. (ed.) Functioning in the workplace. Quantitative and qualitative psychological research. Warszawa: Scholar Publishing House, 2012, pp. 115-127

[40] Pawłowska A. Młodzi w biznesie z perspektywy teorii rozwoju zawodowego. Wyniki badań własnych. in: Glinka B., Pasieczny J. (ed.) Młodzi przedsiębiorcy. Problemy Zarządzania, Warszawa: Wydawnictwo Naukowe WZ UW; 2012.

[41] Sargent L.D., Bataille Ch.D., Vough H.C., Dea M.Metaphors for retirement: Unshackled from schedules. Journal of Vocational Behavior 2011; 79 pp. 315-324

[42] Bolesta-Kukułka, K. Decyzje menedżerskie w teorii i praktyce zarządzania. Warszawa: Wydawnictwo Naukowe Wydziału Zarządzania UW; 2003.

[43] Bolesta-Kukułka, K. Socjologia ogólna. Warszawa: Wydawnictwo Naukowe WZ UW; 2003.

[44] Morgan G. Wyobraźnia organizacyjna. Warszawa: PWN; 2002. 